ROCZNIKI HUMANISTYCZNE

Tom LXIX, zeszyt 2 - 2021

DOI: https://doi.org/10.18290/rh21692-9

PAWEŁ SMOLEŃ, MARZENA ŚWISTAK

\author{
THE IDEA OF UNIVERSITAS STUDIORUM \\ IN VIEW OF THE PRINCIPLE GUIDELINES \\ OF THE ACT 2.0. SOME REFLECTIONS \\ ON THE MISSION OF THE CONTEMPORARY UNIVERSITY
}

\author{
GENERAL REMARKS
}

All reflections on the university, especially its mission, are focused primarily on the community of teachers and students. ${ }^{1}$ Such a community is the fundamental basis of the model of ideal higher education institution. The Middle Ages are widely considered the 'creator' of the university. However, one can come across the view that the history of schools of academic nature can be

Dr. hab. PAwę Smolé - Associated Professor, Department of Finance and Finance Law, Institute of Law, Faculty of Law, Canon Law and Administration at the John Paul II Catholic University of Lublin; correspondence address: Aleje Racławickie 14, 20-950 Lublin; e-mail: pasmo@kul.pl; ORCID: https://orcid.org/0000-0001-6607-3446.

Dr. MARZENA ŚWISTAK - Department of IT Law and Legal Professions, Faculty of Law and Administration at the Maria Curie-Skłodowska University in Lublin; correspondence address: Plac Marii Skłodowskiej-Curie 5, 20-031 Lublin; e-mail: marzena.swistak@poczta.umcs.lublin.pl; ORCID: https://orcid.org/0000-0002-3910-6019.

${ }^{1}$ Such terminology referring to the university are used by J. LASKOWSKA, "Pomiędzy specjalistą i humanistą - rola uniwersytetu w kształtowaniu współczesnej gospodarki," Anthropos? Czasopismo Naukowe przy Wydziale Filologicznym Uniwersytetu Ślaskiego no. 18-19 (2012): 30; the aspect of community as strong interpersonal bonds - universitas professorum et scholarum based on the community of aspiration, goals and methods is stressed by A. HuTNIKIEWICZ, "Żywe tradycje uniwersytetu europejskiego - odpowiedź na ankietę KUL," in Tożsamość uniwersytetu. Antologia tekstów Profesorów Uniwersytetu Mikołaja Kopernika, ed. W. Wincławski (Toruń: Wydawnictwo Uniwersytetu Mikołaja Kopernika, 1994), 40-41. 
traced as far back as in Ancient Greece. ${ }^{2}$ Exploring philosophy and scientific studies had both an individual and a social dimension. The oldest and most famous organisational forms of educational institutions in Greece include the Pythagorean Society and the Platonic Academy. Undoubtedly, the centres created in the Middle East, India and China were also the models that influenced the development of higher education in medieval Europe. ${ }^{3}$ During the early Middle Ages, the Arab caliphates and the Byzantine Empire were the most scientifically developed areas in the world. ${ }^{4}$ Baghdad and Constantinople were even considered capitals of science. ${ }^{5}$

It is argued that the classical idea of the university consists of three traditions: first, the tradition of ancient schools, in particular the Plato Academy and Aristotle's Lyceum, second, early medieval corporatism (guilds), third, the tradition of autonomous, republican municipal communities, which were founded in the 10th to 12 th centuries in northern Italy (where also first universities used to be established). ${ }^{6}$ Based on these interrelated elements, the full, rational search for truth, good, and beauty within the community and for the community emerged. ${ }^{7}$ As early as at that time, the first signs of the university's mission were taking shape, despite the lack of an institutional form. However, they did not take on specific forms and frameworks until the Middle Ages, when the dynamic process of shaping the multifaceted idea of university began.

${ }^{2}$ T. CZEŻOwSKI, "Uniwersytet nowoczesny," in Tożsamość uniwersytetu. Antologia tekstów, 13; the same view in T. CZEżowsKI, "Uniwersytet nowoczesny," in IDEM, O uniwersytecie $i$ studiach uniwersyteckich (Toruń: Księgarnia Naukowa T. Szczęsny i S-ka, 1946), 5; J. BumP, "Historia uniwersytetu jako instytucji naukowej," Internet Archive, accessed February 18, 2020, http://web. archive.org/web/20150712015657/http://www.cwrl.utexas.edu:80/ bump/OriginUniversities.html.

${ }^{3}$ The following Chinese schools are worth mentioning: Shang-Xiang, Taixue and Guozijian, as well as the Nalanda academy (operating in the period 500-1193 in India), as stated in BuMP, "Historia uniwersytetu."

${ }^{4}$ S.F. AlataS, "From Jāmi'ah to University: Multiculturalism and Christian-Muslim Dialogue," Current Sociology 54, no. 1 (2006): 112-132; G. HugH, A history of Christian-Muslim Relations (Edinburgh: Edinburgh University Press, 2000), 99.

${ }^{5}$ Unlike Western Europe, both Byzantium and the whole Arabic world kept the achievements of the Greeks, Romans and other peoples of the Eastern Roman Empire. The following schools operated in this region: Dar al-Hikma (House of Wisdom) in Baghdad, Al-Qarawiyyin University in Fez since 859, and Al-Azhar University in Cairo since 988 (see BUMP, "Historia uniwersytetu"); K. WENTA, “Akademia jako źródło wiedzy oraz przestrzeń kształcenia i wychowania,” Pedagogika Szkoty Wyższej no. 1 (2011): 92.

${ }^{6}$ K.Z. SowA, "Idea uniwersytetu," in Gdy myślę uniwersytet (Kraków: Wydawnictwo Uniwersytetu Jagiellońskiego, 2009), 11-12; K.M. CWYNAR, "Idea uniwersytetu w kulturze europejskiej," Polityka i Spoleczeństwo 2 (2005): 46.

${ }^{7}$ Sowa, "Idea uniwersytetu," 13 


\section{UNIVERSITAS STUDIORUM - THE CONCEPT AND GENESIS}

Since the beginnings of universities in Europe, values such as truth, autonomy, pluralism, freedom and universality have been close to them and have intertwined in the mainstream process of seeking truth. The denial of these values was detrimental to the very heart of the idea of university. ${ }^{8}$ Referring to the dictionary term of university, it should be mentioned that it derives from the Latin word universitas, which just means: generality, universality, ${ }^{9}$ whole, unity. ${ }^{10}$ The term 'university' was originally associated with the medieval

${ }^{8}$ J. BRZEZIŃSKI, "Erozja norm akademickich. Próba diagnozy,” Testy Drugie no. 1-2 (2006): 9; J.M. BRZEZIŃSKI, "Etos akademicki," Forum dydaktyczne no. 7-8 (2011): 9-16; cf. J. BRZEZIŃSKI, "O cnotach uniwersyteckich," in Wokót historii i polityki. Studia z dziejów XIX i XX w. dedykowane Prof. W. Wrzesińskiemu w siedemdziesiąta rocznicę urodzin, eds. S. Ciesielski, T. Kulak, K. Ruchniewicz, J. Tyszkiewicz (Toruń: Wydawnictwo Adam Marszałek, 2004); B. SKARGA, "O Uniwersytecie," Białostockie Teki Historyczne 5 (2007): 9; A. GIEYSZOR, "Systemy wartości w tradycji uniwersyteckiej," in Idea Uniwersytetu u schytku tysiaclecia, ed. H. Żytkowicz (Warszawa: Fundacja na Rzecz Nauki Polskiej, Wydawnictwo Naukowe Scholar, 1998), 11; J.M. BRZEZIŃSKI, "Doświadczenia uniwersytetu europejskiego a przyszła organizacja szkolnictwa wyższego w Polsce," in Idea Uniwersytetu u schytku tysiaclecia, 91. The need to strive for truth in the case of Catholic universities is also stressed by S. SAWICKI, O uniwersytecie katolickim - zarys modelu (Lublin: Towarzystwo Naukowe KUL, 2015), 10; HUTNIKIEWICZ, "Żywe tradycje uniwersytetu europejskiego," 40; pluralism and freedom of ideas as the values to be typical of the university are pointed to in "Uniwersytet mojej młodości. Z Prof. Arturem Hutnikiewiczem z UMK rozmawia Roman Erdman," interview by Roman Erdman, in Tożsamość uniwersytetu. Antologia, 61-62; the aspect of external and internal openness of the university is noted by M.A. KRĄPIEC, "O otwartość uniwersytetu," in O uniwersytecie. Wykłady otwarte imienia Ojca Profesora Mieczysława A. Krapca OP, eds. A. Maryniarczyk, T. Duma, K. Stępień (Lublin: Polskie Towarzystwo Tomasza z Akwinu, 2014), 77-95; L.C. Bollinger, “The Idea of a University,” Wall Street Journal, October 15, 2003, www.proquest.com; A. ISKRA-PACZKOWSKA, "Inkluzywna a ekskluzywna rola uniwersytetu we wspólnocie," in Idea uniwersytetu dziś. Perspektywa filozoficzna (Rzeszów: Wydawnictwo Uniwersytetu Rzeszowskiego, 2012), 150.

${ }^{9}$ Universality refers both to the universality of teaching and the universality of students and teachers. Two aspects of this principle are distinguished. Firstly, it is understood as enabling all those interested to unrestrictedly acquire knowledge, and secondly, the aspect of the whole, the comprehensive nature (J. WYROZUMSKI, "Powszechność nauk w systemie uniwersyteckim dawniej i dziś," in Idea Uniwersytetu u schytku tysiaclecia, 16, 18-19; W. FURMANEK, "Wartości uniwersytetu w nauczaniu Ojca Świętego Jana Pawła II," in Idea uniwersytetu w nauczaniu Jana Pawła II, ed. W. Furmanek (Rzeszów: Wydawnictwo Uniwersytetu Rzeszowskiego, 2006), 42; W. FURMANEK, "Funkcje teleologiczne uniwersytetu w świetle transformacji cywilizacyjnych," in Idea uniwersytetu w nauczaniu Jana Pawła II, 131). Similarly: Hutnikiewicz, "Żywe tradycje uniwersytetu europejskiego," 40; J. STARNAWSKI, "O uniwersytetach średniowiecznych i ich dziedzictwie," in Uniwersytet światynia wiedzy (Łódź: 2007), 6.

${ }^{10}$ Wenta, Akademia jako źródło wiedzy, 92; Stownik języka polskiego ed. W. Doroszewski, accessed February 18, 2020, https://sjp.pwn.pl/doroszewski/uniwersytet;5511640.html; similarly A. ANDRZEJUK, "Universitas? Mistrz? Uczeń? O roli uniwersytetów dzisiaj," in Debaty UKSWordzkie 
construction of universitas magistrorum et scholarium, which referred to the school community. ${ }^{11}$ Thus, the word universitas referred to the corporation of students or both teachers and students. ${ }^{12}$ It was a specific way of bringing together and organizing people united by a common goal, interest and penchant, which gave this structure its specific identity. ${ }^{13}$ However, regarding a higher institution, where education and teaching were structurally carried out, it used to be called a studium. It was an institution where research and education took place. The necessary condition for the realization of these goals was: zeal and diligence at work, love for the truth as well as the passion and enthusiasm of those who conduct research and gain education. The passion for seeking the truth became the determinant of the specific way of life. ${ }^{14}$ To distinguish this institution from other schools, including particular schools, it was referred to as studium generale, due to its supra-regional character and the broad, systemic scope of education, which ended with the award of an academic degree. It was not until the end of the Middle Ages that

cz. 1, eds. K. Flader-Rzeszowska, K. Marcyński, J.A. Sobkowiak (Warszawa: Wydawnictwo Uniwersytetu Kardynała Stefana Wyszyńskiego, 2016), 107-108; CzEżowsKI, "Uniwersytet nowoczesny," in Tożsamość uniwersytetu. Antologia tekstów, 16; CzEżowsKI, "Uniwersytet nowoczesny," in IDEM, O uniwersytecie, 8; J. WILKIN, "Jaka powinna być misja uniwersytetu w warunkach przełomu cywilizacyjnego?," in Misja i stużebność uniwersytetu w XXI w., ed. J. Woźnicki (Warszawa: Oficyna Wydawnicza Politechniki Warszawskiej, 2013), 26.

${ }^{11}$ M.A. KRĄPIEC, "Uniwersytet," in Powszechna Encyklopedia Filozofii, vol. IX, eds. M.A. Krąpiec, A. Maryniarczyk (Lublin: Polskie Towarzystwo Tomasza z Akwinu, 2000), ptta.pl/pef/pdf/u/ uniwersytet.pdf. Unlike universitas civium, i.e. the community of municipal citizens (see CZEżowski, "Uniwersytet nowoczesny," in Tożsamość uniwersytetu. Antologia, 16, the same view in CZEŻowsKI, "Uniwersytet nowoczesny," in IDEM, O Uniwersytecie, 8).

${ }^{12}$ As in: M. MARKOWSKI, Uniwersytet Krakowski w kontekście środkowoeuropejskim późnego średniowiecza i wczesnej nowożytności (Olecko: Wydawnictwo Wszechnicy Mazurskiej, 2005), 17; P. MichaUd-QuANTIN, Universitas. Expressions du mouvement communautaire dans le Moyen Age latin (Paris: Vrin, 1970), 35 et seq.; T.E. HufF, The rise of Early Modern Science. Islam, China and the West (Cambridge: Cambridge University Press, 2003), 133. K. TwARDOwSKI, "Rozwój i organizacja uniwersytetów," in K. TWARDOWSKI, Lwowskie wyktady akademickie, vol. I: Wyktady o idei Uniwersytetu, compiled by R. Kuliniak, D. Leszczyna, M. Pandura, Ł. Ratajczak (Kęty: Wydawnictwo Marek Derewiecki, 2018), 233 argues that universitas does not mean any highest-level school, but states that it is a corporation, association, union of teachers and students (universitas magistrorum et scholarium) in the studium generale. So it is a peculiar kind of corporation. See also J. BASZKIEWICZ, Młodość uniwersytetów (Warszawa: Wydawnictwo “Żak”, 1997), 35.

${ }^{13}$ T. SŁAWEK, "Uniwersytet, jego powaga i warunki," in Fenomen uniwersytetu, eds. A. Grzegorczyk, J. Sójka (Poznań: Wydawnictwo Naukowe UAM, 2008), 85-86, who also points to the difference between universitas and societas, which is based not on common goals, but on a bond conditioned by mutual loyalty of individuals.

${ }^{14}$ As in: J. SONDEL, Stownik łacińsko-polski dla prawników i historyków (Kraków: Universitas, 2005), 905 and A. LEKKA-KOWALIK, "Uniwersytet jako firma usługowa - szansa czy klęska?," Ethos no. 85-86 (2009): 53. 
the name of the university began to be applied to the institution as a whole, ${ }^{15}$ and seven liberated arts lost their importance, replaced by the pursuit of the development of science. ${ }^{16}$

The community of students and teachers - masters and disciples (universitas studiorum) was to respond to the complex, both present and future problems of the world. ${ }^{17}$ The university created an enormous European educational community, which was continued by people who creatively sought truth, building on the foundation of mutual respect and friendship. ${ }^{18}$ As is argued in the literature on the subject, the community nature inherent in universitas studiorum was implemented in four dimensions through: a unified curriculum at all universities, ${ }^{19}$ the introduction of a uniform application of the Latin language at the university, the movement of students and teachers between universities and the mutual recognition of academic degrees and titles. ${ }^{20}$

${ }^{15}$ The aspect of change in the understanding of the term 'university' as late as in the modern era is pointed to by MARKOWSKI, Uniwersytet Krakowski w kontekście środkowoeuropejskim, 17-18.

${ }^{16}$ M. MARKowSKI, Pierwowzory uniwersytetów (Olecko: Wydawnictwo Wszechnicy Mazurskiej, 2003), 20; MARKOWSKI, Uniwersytet Krakowski w kontekście środkowoeuropejskim, 23.

${ }^{17}$ J. LASKOwSKA, "Pomiędzy specjalistą i humanistą," 30; J. SzMYD, "Idea uniwersytetu klasycznego a jakość człowieka," Edukacja Filozoficzna, specjal issue (2016): 47; Z. ZIEMBIŃSKI, "What Can Be Saved of the Idea of the University?," in The Idea of the University, eds. J. Brzeziński, L. Nowak (Amsterdam-Atlanta: Rodopi, 1997), 21.

${ }^{18}$ W.M. NowAK, "Idea uniwersytetu wobec nowej sytuacji kulturowej," in Idea uniwersytetu dziś. Perspektywa filozoficzna (Rzeszów: Wydawnictwo Uniwersytetu Rzeszowskiego, 2012), 67 and cited there in G. STEINER, Nauki mistrzów, transl. J. Łoziński (Poznań: Zysk i S-ka, 2007), 15 et seq. T. SŁAWEK, "Uniwersytet, jego powaga i warunki," 87-88, who points to the 'friendship' that should bind members of the universitas.

${ }^{19}$ In addition to the initial programme of liberated arts, medieval universities also offered courses in medicine, law, philosophy and theology. O. PEDERSEN, The First Universities. Studium Generale and the Origins of University Education in Europe (Cambridge: Cambridge University Press, 2000), 133. The studies based on text work: lecturing, commenting and discussing them. The reading of texts led from their literal understanding (littera), through the analysis of arguments (sensus), up to the ultimate goal, i.e. the discovery of its main thought (sententia) - W. SEŃKO, Jak rozumieć filozofię średniowieczna (Kęty: Wydawnictwo Antyk, 2001), 61. The questions and doubts (quaestiones) that arose in the course of the reading had to be clarified by means of comments. There was a hierarchy of texts and authors, depending on the authority they enjoyed. The highest authority was the Bible, and in terms of philosophy such authority was Aristotle (SEŃKO, Jak rozumieć filozofię średniowieczna, 56). Disputes of a strictly defined form played an important role at the university. They used to start by identifying a problem. Then arguments for and against the thesis were collected. The dispute was concluded with an explanation of the problem concerned. Many medieval philosophical and theological treatises take their form from this method of discussion (pro-contra-solutio). S. SWIEŻAWSKI, Dzieje europejskiej filozofii klasycznej (Warszawa-Wrocław: Wydawnictwo Naukowe PWN, 2000), 555 et seq.

${ }^{20}$ S. WALToś, "Korzenie współczesnego szkolnictwa wyższego - ścieżki tradycji," in Szkolnictwo wyższe w Polsce. Ustrój - prawo - organizacja, eds. S. Waltoś, A. Rozmus (Warszawa: Wolters Kluwer, 2012), 17. 
The term universitas appeared at the earliest in schools in Bologna and Paris, expanding its use throughout the Middle Ages, becoming more popular than the concept of studium generale. The notion of universitas had no institutional significance (unlike studium generale, where the difference between these concepts disappeared only in the 15 th century). At that time, the University was a voluntary, collective, homogeneous community, an autonomous corporation of either students, or scholars and teachers, operating in the field of didactics with its own applicable law. ${ }^{21}$ Only elite corporations of teachers that represented a high level of teaching could seek recognition as an universitas magistrorum et scholarium. At that time, such a corporation applied its own law, and was not supervised by any external institutions. It had social security facilities (e.g. tax exemptions, rent payment relief, exemption from military service), while enjoying the privilege of self-government in terms of organisation and adoption of internal regulations. A universitas that earned scientific prestige could apply for a papal or imperial privilege, which greatly increased its prestige.

\section{OUTLINE OF THE IDEA OF UNIVERSITY}

The functioning of ancient forms of scientific activity and education and the emergence of the first medieval European universities are inevitably linked to the shaping of the idea of university. This process was, and still is, not uniform in its course. Medieval universities have become a solid reference point in academic activity, allowing, on the one hand, the intensive development of this form of research and education, and, on the other, releasing in later centuries a number of currents that question their achievements. An extensive catalogue of theoretical concepts was thus created, which have shaped the diverse understanding of the idea and mission of university. Focusing only on the main currents, it is worth mentioning: the idea of the university as approached by J. Newman, W. von Humboldt, K. Jaspers or other selected views in which the state of modern university is diagnosed.

J. Newman in The Idea of University stressed that the university teaches universal knowledge, which constitutes a whole with individual disciplines. They are mutually connected and complementary. The main purpose of the university is teaching and educating understood as the intellectual formation

${ }^{21}$ MARKowSKI, Pierwowzory uniwersytetów, 71-72. 
of the student's personality, as part of a process of an individual and lasting nature. In this context, he believed that it was the university's responsibility to communicate and spread knowledge, not to focus on its progress. ${ }^{22}$ The goal should be to pursue the truth. Therefore, the university should be focused on achieving an intellectual rather than a moral goal. J. Newman stresses that the university should cover a number of disciplines, without excluding any of them from the education system. Such harmony guarantees proper intellectual development.

W. von Humboldt is recognized as the originator of the idea of classical university (traditional, liberal university). ${ }^{23} \mathrm{He}$ stressed the importance of freedom to conduct research, freedom to express one's views and freedom of teaching within a university that combines all scientific institutions (including academies and institutes). ${ }^{24}$ The University is a place of research and teaching, where the development and transmission of science is carried out. ${ }^{25} \mathrm{~W}$. von Humboldt, in creating this idea, took on the concept of pure science, which is being acquired but not discovered. He argued that the university should be based on three pillars: the unity of knowledge, unity of research and education, and the unity of professors and students. Like Newman, he assumed the cooperation and mutual permeation of all scientific disciplines. He clearly referred to medieval models. He considered the pursuit of truth to be the primary goal of science, while preserving the unity of research and education. He emphasized the need to build a community of students and professors, ${ }^{26}$ assuming

22 J.H. Newman, Idea uniwersytetu (Warszawa: Państwowe Wydawnictwo Naukowe, 1990), 79. The relationship of J.H. Newman's concept with the ancient thought is being pointed out, especially as regards the very definition of the university, the understanding of the university as a place of formation of the intellect (H. BIEDRZYCKA, "Zagadnienie zależności "The Idea of a University” J.H. Newmana od starożytności klasycznej,” Roczniki Humanistyczne 4, no. 2 (1953): 113-122). On the other hand, I. SŁAwIŃSKA, "Idea uniwersytetu (Review of J.H. Newman's Idea uniwersytetu)," Ethos no. 23 (1993): 222 points out that J.H. Newman in the concept of 'liberal knowledge' refers to the classical model and the medieval idea, i.e. selfless humanistic and philosophical culture, which was to aim at the intellectual proficiency of the student. J.W. Osborne, "John Henry Newman and the Idea of a Uuniversity," The Journal of the Rutgers University Library 42, no. 1 (1980): 43-44.

${ }^{23}$ I. ZAKOWICZ, "Idea uniwersytetu Wilhelma von Humboldta - kontynuacja czy zmierzch," Ogrody Nauk i Sztuk no. 2 (2012): 62.

${ }^{24}$ W. VON HUMBOLDT, "Wniosek o powołanie uniwersytetu w Berlinie," in ANDRZEJEWSKI, Wilhelm von Humboldt, 234 et seq.

${ }^{25}$ W. vON HuMBOLDT, “Organizacja instytucji naukowych,” in ANDRZEJEWSKI, Wilhelm von Humboldt, 240 and 249.

${ }^{26}$ ZAKOWICZ, "Idea uniwersytetu Wilhelma von Humboldta," 62. 
that education should be based on a master-student relationship, on a partnership dialogue and the pursuit of truth. ${ }^{27}$

The Humboldt's concept was revived after World War II by K. Jaspers. ${ }^{28}$ Emphasizing the constant dynamics of the university's evolution process, he appealed for the preservation of the timeless (fundamental) values that shape its essence. ${ }^{29} \mathrm{He}$ pointed to the necessity of creating a community, ${ }^{30}$ unity of sciences ${ }^{31}$ as well as searching for the truth and passing it on to students. ${ }^{32}$ The implementation of these tasks will be possible if the university obtains a guarantee of freedom of research and autonomy. ${ }^{33}$ The university should not yield to any pressure and should avoid getting involved in the implementation of utilitarian or even political goals. ${ }^{34}$ Like Humboldt, he pointed to three tasks: research, teaching and upbringing. At the same time, it seems that he put more emphasis on education. He opposed the growing phenomenon of mass studies, arguing that they should be elitist. ${ }^{35}$

The K. Jaspers' idea seems to be an expression of longing for the idea of a classical university in the conditions of the crisis of this institution progressing in the 20th century. At this point, it is worth recalling the view of

${ }^{27}$ IBIDEM, 63; K. SAUERLAND, “Idea uniwersytetu - aktualność tradycji Humboldta?," Nauka I Szkolnictwo Wyższe no. 2 (28) (2006): 90; Cf. also P.U. HoHENDAHL, "Humboldt Revisited: Liberal Education, University Reform, and the Opposition to the Neoliberal University," New German Critique no. 113 (2011): 159-196.

${ }^{28} \mathrm{~K}$. Jaspers does not directly come to terms with the situation of universities between 1933 and 1945. He also does not consider what mechanisms in the organisation of German higher education influenced their subordination to totalitarian power. He refers directly to fundamental aspects of the Humboldt's idea (as stated in P. SosnOwSKA, "Między ciągłością i zerwaniem. Co pozostaje z Bildung?," Kultura Wspótczesna 1 (99) (2018): 179). See also L. KOMOROwSKI, "Idea czy utopia," Pauza Akademicka no. 415 (2018): 2, who points out that K. Jaspers' work was renewed in several difficult moments for Germany, with an aim to restore their former glory, while his views continue to be topical. For example, K. Jaspers' idea and his desire for the university to maintain its unity and community is referred to by J. Gowin in his congratulatory letter of 30 September 2019 addressed to the Rector of the University of Gdańsk, in which he writes that he would like the university to be "a community of free and happy people, developing their humanity in every aspect and dimension." T. GADACZ, "Wstęp do wydania polskiego," in K. JASPERS, Idea uniwersytetu (Warszawa: Narodowe Centrum Kultury, 2017), 12.

${ }^{29}$ GADACZ, "Wstęp do wydania polskiego," 13.

${ }^{30}$ IBIDEM, 13; JASPERS, Idea uniwersytetu, 99; SOSNOwSKA, "Między ciągłością i zerwaniem,” 179.

${ }^{31} \mathrm{He}$ also shows the characteristic afirmation of W. von Humboldt's views on his concept of unity (as stated also by SoSNOwSKA, "Między ciągłością i zerwaniem," 133).

32 JASPERS, Idea uniwersytetu, 31.

${ }^{33}$ IBIDEM, 176.

${ }^{34}$ IBIDEM, 31, 79-82; GADACZ, "Wstęp do wydania polskiego," 14-16.

35 JASPERS, Idea uniwersytetu, 143, 153-154; GADACZ, "Wstęp do wydania polskiego," 18-19. 
Hans-Georg Gadamer, who stated that it was no longer possible to get back to Humboldt's ideals. ${ }^{36}$ He points to the phenomena already known in Polish circumstances. First of all, these are the mass character of studies, the decomposition of the professor-student relationship, the disintegration of the unity of sciences as a result of growing specialization, and the breakdown of the unity of research and teaching. ${ }^{37}$ At the same time, Gadamer goes for the protection of as many conditions inherent in the classical university model as possible. ${ }^{38}$

The gradual degradation of classical values in the functioning of the contemporary university was noted by José Ortega y Gasset. He did not support ad hoc remedial actions limited to cyclical, current removal of irregularities emerging at a given time, as he considered these actions to be ostensible. $\mathrm{He}$ advocated introducing a thorough reform that would provide a new framework for the university activities and, above all, would redefine its mission. ${ }^{39} \mathrm{He}$ considered the university a living organism, undergoing changes, susceptible to the influence of its surroundings. This excludes direct application of well known, premade university models (including ideal medieval models), detached from the current cultural, economic and social conditions. ${ }^{40}$ According to J. Ortega y Gasset, the contemporary university, following the paths of specialization, leads to fragmentation of man. ${ }^{41}$ It releases into the world new professionally educated 'barbarians'. ${ }^{42}$

The university of the twentieth century focuses on three main tasks: the transmission of culture, profession teaching, research and education of new

\footnotetext{
${ }^{36}$ As pointed to by SOSNOwSKA, "Między ciągłością i zerwaniem," 181; H.-G. GADAMER presented his vision of the crisis of universities of the mid-20th century in the speech delivered in 1986 on the occasion of the 600th anniversary of the Heidelberg University.

${ }^{37}$ H.-G. GADAMER, "Idea uniwersytetu - wczoraj, dziś, jutro," in IDEM, Teoria, etyka, edukacja. Eseje wybrane (Warszawa: Wydawnictwa Uniwersytetu Warszawskiego, 2008), 245; P. SosNOwsKA, "Idea niemieckiego uniwersytetu: mit Humboldta?," Teraźniejszość - Człowiek-Edukacja no. 4 (60) (2012): 132.

${ }^{38}$ SoSNOWSKA, "Między ciągłością i zerwaniem," 181.

${ }^{39}$ Of course, it is acceptable to use the experience of other countries, but only in order to acquire information, not to apply them directly as a model. J. ORTEGA Y GASSET, "Misja uniwersytetu," Znak no. 288 (1978): 712-715.

${ }^{40}$ ORTEGa y GASSET, "Misja uniwersytetu," 716 argues that the remains of ideal medieval solutions that are still noticeable in the 20th century, are just a remnant of something that used to be the core of higher education. This is so because the medieval university lived according to the medieval way of life.

${ }^{41}$ Ortega y GASSET, "Misja uniwersytetu," 718.

${ }^{42}$ IBIDEM, 717.
} 
scientists. ${ }^{43}$ At the same time, J. Ortega y Gasset proposed to change the university profile and evaluation criteria of the university, which should teach not what it wants to teach, but what it should teach. ${ }^{44}$ In this context, the university first and foremost provides the education that the average person should have as a cultural individual at the level of their time. ${ }^{45}$ This minimalist vision of activities of the university does not constitute the final version of its mission and responsibilities. J. Ortega y Gasset presented rather a vision of the institution with its current limitations. He has also stressed that science is the source of the university's existence and thus it goes in line with its nature. Of course, it cannot be alienated from the contemporary aspects of the whole environment in which it operates. ${ }^{46}$

The contemporary views include also the opinion of Bill Readings, who outlined a vision of the new type of university as an institution constituting a post-historical model. He believed that the culture-forming role of the state is disappearing, and thus the tradition of the classic W. Humboldt's university declines. The university is even falling to ruins, in which it is no longer a matter of establishing a perfect community of professors and students. ${ }^{47}$ Scientists are turning into bureaucrats and students into consumers of knowledge. ${ }^{48}$ The autonomy of the university is being replaced by the bureaucratic (technical) management model used in business organisations. The main position is given to the criterion of effectiveness of research and teaching, which has a particular negative impact on the evaluation of the humanities. ${ }^{49}$ This phenomenon is called 'Americanisation' and refers to the wider process of globalisation. ${ }^{50} \mathrm{He}$ proposes a thesis that the university has become a transnational bureaucratic corporation, more and more linked to various forms of power, such as the European Union. ${ }^{51}$

He notes that the modern university has three basic tasks: research, teaching and administration. ${ }^{52} \mathrm{He}$ calls for defining the role of the university anew, but not just by simple negation of the whole classical tradition or approval of the university model as a technocratic corporation. B. Readings is repulsed, above all, by the adoption of a dominant position of scientific research. ${ }^{53}$

\footnotetext{
${ }^{43}$ IBIDEM, 719.

${ }^{44}$ IBIDEM, 720.

${ }^{45}$ IBIDEM, 720-726.

${ }^{46}$ IBIDEM, 730.

${ }^{47}$ B. ReAdings, Uniwersytet w ruinie (Warszawa: Narodowe Centrum Kultury, 2017), 196

${ }^{48}$ M. WERNER, "Wstęp do wydania polskiego," in READINGS, Uniwersytet w ruinie, 7-8.

${ }^{49}$ Werner, "Wstęp do wydania polskiego," 8.

${ }^{50}$ READINGS, Uniwersytet $w$ ruinie, 18.

${ }^{51}$ IBIDEM, 19.

52 IBIDEM, 194.

${ }^{53}$ IBIDEM, 196.
} 
The Bill Readings' idea of university mentioned above addresses the increasingly popular in Europe concept of including business-like principles in the structure of the university, and even subjecting it even to the rules of the market game. This can lead to the phenomenon of 'university marketisation' which turns it into a business. Generally speaking, this is intended to open the university to the surrounding world, thanks to which, it becomes in general perception an institution more adapted to the needs of society. Such an assumption mobilizes the academic staff to undertake specialisation efforts and acquire competence to undertake scientific discussion in all areas of current challenges. ${ }^{54}$

Also in Poland, as part of the debate carried out in the context of the reform of higher education, the need for fundamental changes in the perception of the university's operation was mentioned. The view was cited that "the university is no longer a quiet place where students are taught, research is done and the universe is contemplated at an equal pace, as in previous centuries. The university is a powerful, complex, demanding and competitive business that requires continued large-scale investment." It has also been noted that the changes taking place in the world "are pushing the higher education system more and more towards the market (or the quasi-market). ${ }^{.55}$

\section{CONCEPTS OF THE HIGHER EDUCATION SYSTEM REFORM IN POLAND}

The issue of the form and future of Polish higher education was so important that they became a key element in the designation speeches of successive prime ministers. The introduction of an effective method of reforming the higher education system in Poland has been considered a pressing problem. Therefore, in recent years, these issues have appeared many times in the statements of government members. They used to point out that higher education played an important role in educating young generations of Poles, and the quality of research conducted at universities translates directly into the development of the Polish economy. A well-functioning higher education system should therefore be one of the national priorities. Scientists should be provided with decent working conditions, so that they feel that their work is appreciated, and that

\footnotetext{
${ }^{54}$ R. BARNETT, Realising the University in an Age of Supercomplexity (Buckingham: Society for Research into Higher Education \& Open University Press, 1999), 74-75.

${ }^{55}$ See M. KwIEK, Transformacje uniwersytetu. Zmiany instytucjonalne i ewolucje polityki edukacyjnej w Europie (Poznań: Wydawnictwo Naukowe UAM, 2010), 97-98.
} 
the state's actions are aimed directly at supporting their efforts. Only in such an environment is the mission of the university fulfilled, both in financial and organisational terms. ${ }^{56}$ The need to continue the initiated reforms of higher education was emphasized, concluding that the modern economy is an economy cooperating with science, which should lay the foundations for economic development to a much greater extent than today. It was assumed that these goals could only be achieved by thorough reforms that would lead to the formation of national elites and stop the 'brain drain', i.e. a permanent outflow of some Polish scientists to foreign universities and research institutes. ${ }^{57}$

When undertaking the work on the breakthrough reform of the higher education system, it was decided that it could not be developed only in government offices. It is essential that the resulting regulation takes into account the voice of the broadest possible group from the academic world. In view of the above, it was decided to outsource the development of a concept for the planned reform to external entities. Such a solution should be considered novel ${ }^{58}$ It used to be noted that this would make the participation of academia in legislative work real, and the resulting regulation would take optimal account of the needs of scholars. To this end, pursuant to the Communication of the Minister of Science and Higher Education of 23 February 2016 on the establishment of a project called "Act 2.0 - guidelines for the higher education system", 59 a competition was announced in which the winners were to carry out scientific research and, as a result, to present a proposal for new regulations in the field of higher education. ${ }^{60}$ Of the dozen or so teams that entered the competition, three of them won. These were projects prepared by teams led by:

1. Professor A. Radwan,

2. Professor H. Izdebski,

3. Professor M. Kwiek. ${ }^{6}$

${ }^{56}$ Designation speech of President of the Council of Ministers Beata Szydło of 18 November 2015, as cited in the explanatory note to the Draft Act - Law on Higher Education.

${ }^{57}$ Designation speech of President of the Council of Ministers Mateusz Morawiecki of 12 December 2017, as cited in the explanatory note to the Draft Act - Law on Higher Education.

${ }^{58}$ See also L. TOMALA, "Ustawa 2.0. Pierwsza od 12 lat całościowa reforma uczelni, przygotowana w nietypowym trybie,” Nauka w Polsce, last modified September 18, 2017, http://naukawpolsce.pap.pl/ aktualnosci/news\%2C459708\%2Custawa-20/pierwsza-od-12-lat-calosciowa-reforma-uczelni.html.

${ }^{59}$ Monitor Polski, item 191.

${ }^{60}$ See Ogłoszenie o konkursie Ministra Nauki i Szkolnictwa Wyższego w ramach przedsięwzięcia pod nazwą "Ustawa 2.0 - Założenia systemu szkolnictwa wyższego."

${ }^{61}$ These were the following interdisciplinary teams: the team led by Professor H. Izdebski (SWPS University of Social Sciences and Humanities), the team led by Professor M. Kwiek (A. Mickiewicz University in Poznań), the team led by Professor A. Radwan (Allerhand Institute). 
The Professor A. Radwan's team ${ }^{62}$ has considered that the primary objective of universities is to provide knowledge for the economy and the cultural capital for society. It therefore points out, in line with the classical idea of the university, that it should have the culture-forming function. ${ }^{63}$ In his opinion, scholars often make a mistake, which involves the opposition: enterprising university vs. Humboldt's university, or 'epublic of scholars' vs. 'efficient corporation'. According to Professor A. Radwan, such contradictions are unfounded. ${ }^{64}$ Undoubtedly, the university's mission differs from that of companies that focus on making a profit. ${ }^{65}$ This does not mean that the university should have remained immersed in the past. On the contrary, it should deftly use properly selected market mechanisms to carry out its mission more effectively. Thus, the idea is that university managers should look for a certain balance in this regard, seeking to obtain a golden mean between the selfless 'pursuit of truth' and functioning in a dynamic, self-interested socio-economic environment. ${ }^{66}$ There is no doubt that making good use of market mechanisms

${ }^{62}$ Plus ratio quam vis consuetudinis. Reforma nauki i akademii w Ustawie 2.0. Projekt zatożeń do ustawy Prawo o szkolnictwie wyższym, ed. A. Radwan (Kraków: Instytut Allerhanda, 2017).

${ }^{63}$ Similarly FURMANEK, "Funkcje teleologiczne uniwersytetu," 125. The decline of the university's culture-forming role is seen by Bill Readings, who points out that W. Humboldt's tradition is a thing of the past, because the culture-forming role of the state has just been weakened. The university is becoming a ruin increasingly difficult to live in for the community of scholars and students pursuing the truth together. The ruins of the university no longer provide a refuge for creative thought, turning scholars into bureaucrats, and students into consumers of knowledge. WERNER, "Wstęp do wydania polskiego," 7-8.

${ }^{64}$ It is not clear in what context the author uses the term 'efficient corporation', in particular as to the meaning of the term 'corporation'.

${ }^{65}$ Similarly, the process of replacing the 'community' by the 'corporate' culture is pointed to by T. SŁaweK, Antygona w świecie korporacji. Rozważanie o uniwersytecie $i$ czasach obecnych (Katowice: Wydawnictwo Uniwersytetu Śląskiego, 2002), 73; A question was asked in the literature: why the university should not be a business? First of all, it is about the structure and functions of business and university. The goal of the business (companies, corporations in the market sense) is primarily to earn profits. The university's goal is to "discover and pass on the truth." It's about serving the truth. This means discovering the truth, not excluding a priori any phenomena from the research process, research following its subject matter. This means involving the university in unrestricted learning. In the case of activities of enterprises, even if science-relevant issues arise in the course of the research, the area will only be covered by any activity if there are entities interested in financing. John Paul II in the speech of 9 June 1987 as cited in A. LEKKA-KowALIK, "Dlaczego uniwersytet nie może i nie powinien być biznesem," Przegląd Uniwersytecki KUL 27, no. 6 (2015): 10-11.

${ }^{66}$ The need to strike a balance between service to society and the market economy and the university's mission was addressed by: J. DUDEK, "Etos uniwersytetu a globalny kłopot z jego tożsamością," Studies in Global Ethics and Global Education no. 7 (2017): 40; SŁAWEK, Antygona w świecie korporacji, 75-76; FURMANEK, "Wartości uniwersytetu," 52. 
to implement the university's mission is a challenge in terms of both the idea and organisation. ${ }^{67}$

This team was aware that the planned legislative project should include a longer-term perspective, and the question of the future of the modern universitas studiorum cannot be enclosed in the period of the coming years of activity of the higher education system. In this regard, it emphasized the divergence between the visions of transformation of the modern academic world presented. ${ }^{68}$ The common denominator that is present here is the need to develop in the university the ability to adapt to the inevitable changes: social, technological and economic. ${ }^{69}$ The ability to adapt should result both from the adopted systemic solutions regarding academic governance, including the formation of a system of bodies with their responsibilities, and from a framework organisational structure assuming autonomy in the internal and external dimensions. It was indicated that the goal should be to design an agile university of a multicentric structure, where the freedom of research could be put in practice and, at the same time, a university well managed from a central, navigable level, and using its resources efficiently.

The importance of the subjective aspect was also stressed, given that the university is defined mostly by its human potential. The academic staff is the university's most important resource and value, which determines the quality of the university and the way it pursues its mission. The university is as good as the scientists who constitute it. Universities must have the will to compete for talent, and scientists must have the opportunity to compete fairly for jobs at universities, and thus for access to research resources and infrastructure. The improvement of working conditions should include not only decent

${ }^{67}$ Plus ratio quam vis consuetudinis. Reforma nauki i akademii w Ustawie 2.0, 12.

${ }^{68}$ See Ł. SuŁKOwSKI, Kultura akademicka. Koniec utopii? (Warszawa: Wydawnictwo Naukowe PWN, 2016); P.G. AltBach, "The Past, Present, and Future of the Research University," in The Road to Academic Excellence, eds. P.G. Altbach, J. Salmi (Waszyngton: The World Bank, 2011), 11-32; P.G. AltBACH, "The Realities of Mass Higher Education in a Globalized World," in Higher Education in a Global Society, eds. D.B. Johnstone, M.B. d'Ambrosio, P.J. Yakoboski (Cheltenham: Edward Elgar, 2010), 25-41.

${ }^{69}$ In the provisions of the new project, Magna Charta Universitatum - MCU 2020, Draft 2.2. (9.11.2019) - seem similar. They state that universities are to adapt and respond to changing circumstances, without losing their fundamental purposes and principles (MCU 2020, Draft 2.2. (as of 9.11.2019), paragraph 19, accessed March 7, 2020, http://www.magna-charta.org/magna-chartauniversitatum/mcu-2020). 
salaries, but also empowerment within the structures of universities, including dignity-related aspects. ${ }^{70}$

The essential thing is that Professor Radwan's team concluded that it is no longer possible to make a direct reference to W. von Humboldt's concept in Polish current conditions. The competitive model, covering various segments and niches, was considered appropriate. ${ }^{71}$ The state should be less a creator of the area of higher education than a supervisor and arbiter to ensure the competition and transparency. Administrative requirements and statutory regulation should remain a subsidiary tool.

Consequently, it will be possible to achieve the ultimate goal of the reform, i.e. the improvement of the quality of scientific research, improvement of the international competitiveness of Polish science, qualitative and quantitative improvement in terms of the contribution made by universities to the economy (innovation, commercialisation, technology transfer) and to society (public debate, culture, arts) and strengthening the potential in the field of education (critical thinking, creativity), and consequently better adapting the content to the requirements of the labour market.

The second team, led by Professor H. Izdebski, also emphasized the erosion of the principles of the functioning of university outlined by W. von Humboldt. It was emphasized that ideological disintegration should concern as little as possible the principle of the unity of research and education as well as the principle of academic freedom and autonomy, which should remain the foundations of the university's operation at all times, regardless of the historical context. The bursting in of such trends as globalization, internationalization

\footnotetext{
70 The literature on the idea of the university stresses that being a university man is not only a profession, but a vocation to be a 'citizen of the university' - to seek the truth and defend it, which requires combining both intellectual and moral and aesthetic culture, the latter complementing the former (see also: M. WeBER, "Nauka jako zawód i powołanie," trans. P. Dybel, in IDEM, Polityka jako zawód i powołanie, ed. Z. Krasnodębski (Warszawa: Znak, 1999), 203; CzEŻowsKI, "Uniwersytet nowoczesny," in Tożsamość uniwersytetu. Antologia tekstów, 24; similarly also A. LEKKA-KowALIK, Komodytyzacja wiedzy i uprzemystowienie uniwersytetów: szansa rozwoju kultury czy źródło zagrożeń?, 10, not published). A. NOwICKI, "O dostojeństwie katedr filozoficznych," Annales Universitatis Mariae Curie-Skłodowska. Sectio I 35 (2010): 156, argues that grace (respectability, dignity) characterizes places filled with culture and people who have made a significant contribution to culture, who are the only ones who can disgrace it (page 158). Similarly, see F. ZIEJKA, "Czy można dziś jeszcze mówić o dostojeństwie uniwersytetu?," in Idea uniwersytetu - reaktywacja, eds. P. Sztompka, K. Matuszek (Kraków: Wydawnictwo Uniwersytetu Jagiellońskiego, 2014), 52.

${ }^{71}$ According to the Authors, the study does not specify what 'competitive model' of university is concerned, whether it is a new structural type that takes into account the specificities of a modern university or merely the postulate that the university should make more efficient use of its resources in a market where competition rules apply.
} 
and Europeanization, massification and egalitarisation of higher education, development of competitive, market-based educational institutions, difficulties with maintaining the current share of public funds in financing universities has been notice in the activities of universities. Such phenomena result in that the ethos of academic science is transformed into a specific corporate ethos, and the university gives up its culture-forming and civic mission and goes towards the education of specialists. In such conditions, the post-Humboldt university must become 'entrepreneurial' in the field of education (adjusting to the labour market), and in the field of science it becomes a provider of educational services (to a large extent practical, professional) and research services (mostly applied sciences). ${ }^{72}$ US universities are recognised as models of such universities, and the phenomenon of the Americanisation of the scientific world has transformed higher education. ${ }^{73}$ However, this phenomenon is often subject to criticism. ${ }^{74}$ It has been pointed out that there is still a dilemma: whether the university is a 'temple of knowledge' or a 'factory of graduates'? It is noted that any necessary changes made to the post-Humboldt model must also take into account the negative effects of its introduction, known from other countries, especially when introducing it too fast and too radical. For this reason, direct application of ready-made solutions, at any cost and without taking into account the specific Polish conditions for higher education, will not solve the problem. ${ }^{75}$ The basic goal of the reform should be the development of high-quality human capital in correspondence with the needs of civilisation, the needs of the national economy and the globalised labour market, including scientific work. The point of departure for achieving the assumed objectives of the reform should be the assumption of the need to properly link university autonomy with competitiveness. The reform should ensure the greatest possible productivity of the Polish higher education system as part of the implementation of the principle of university autonomy. It should entail

${ }^{72}$ H. IZDEBSKI, Założenia do projektu ustawy. "Ustawa 2.0. założenia systemu szkolnictwa wyższego" (Warszawa: Uniwersytet SWPS, 2017), 18, https://wzks.uj.edu.pl/documents/41653/136919256/ UAM.projekt.pdf/1e21b91d-6778-44ad-a813-dc31fce67d90.

${ }^{73}$ G. GRÖZINGER and R. RODRÍGUEZ-GÓMEZ, "Managing Higher Education: Introduction," Management Revue 18, no. 2 (2007): 97. This issue contains studies concerning Germany, Mexico, Austria and Denmark (the latter being deemed the most 'Americanised' in Europe). On the US model of higher education, see e.g. A. BeDnARCZYK-PŁACHTA, Status szkoty wyższej jako podmiotu administracji publicznej (Warszawa: Wolters Kluwer, 2016), 48 et seq., as cited in IzDEBSKI, Założenia do projektu ustawy, 1-19.

${ }^{74} \mathrm{H}$. Izdebski refers to the experiences of other European countries (IZDEBSKI, Załozienia do projektu ustawy, 20).

${ }^{75}$ IBIDEM, 21. 
a shift from the focus on quantity (students, staff, publications, etc.) to quality in all three fields, types of missions of higher education institutions, i.e. in education, research and cooperation with the surrounding environment. ${ }^{76}$

The third team, led by Professor M. Kwiek, built an architectural image of a new, reformed system of higher education that would pursue its mission fully, which in his opinion would evolve towards the emergence of three types of universities, pursuing the three types of mission: research, didactic or research-and-didactic. The research mission would be concentrated in properly subsidised centres with the highest scientific achievements (only by that would the so-called scientific excellence be developed at the right level). The didactic mission, including, in particular, providing access to higher education for the general public, cooperation with the labour market in shaping educational curricula, would be carried out by consolidated teaching universities. Research-and-didactic entities would cooperate with the social and economic environment and support the overall development of the regions. By carrying out research and teaching at a high level, they will be able not only to support regional industry, providing practical solutions and innovations, responding to the needs of local communities, but they will also be centres for the training of specialists for both the modern business sector and the dynamically developing public sector. ${ }^{77}$ These types of universities (carrying out three types of missions) are equally important for the sustainable functioning of the country, the economy, and the system of science and higher education. ${ }^{78}$

It seems that reform guidelines proposed by the above teams primarily defend the research vision of the university. The problem of transformation of universities into centres of mass education in Poland is noticed by all. It is unanimously postulated that it is necessary to rebuild research and education at the elite level, allowing to operate in the international arena. The need for the competition between universities is also emphasized.

${ }^{76}$ IBIDEM, 23. Negative effects of massification of science in universities and the need to change this situation has been pointed to by Hutnikiewicz, "Żywe tradycje uniwersytetu europejskiego," 42-43; H. KIEREŚ, "Uczony - suweren czy funkcjonariusz?," Człowiek w kulturze. Jaka tożsamość uniwersytetu? no. 21 (2009/2010): 94-95; M. KRĘGLEWSKI, "Mój uniwersytet," in Fenomen uniwersytetu, eds. A. Grzegorczyk, J. Sójka (Poznań: Wydawnictwo Naukowe UAM, 2008), 39; similarly: J.M. ZIELIŃSKI, "Komentarz do art. 2," in H. IZDEBSKI, J.M. ZIELIŃSKI, Prawo o szkolnictwie wyższym i nauce. Komentarz (Warszawa: Wolters Kluwer, 2019), LEX.

${ }^{77}$ The importance of the so-called 'third mission' to be carried out by universities is noted also by Plus ratio quam vis consuetudinis. Reforma nauki i akademii w Ustawie 2.0, 256; IzDEBSKI, Założenia do projektu ustawy, 10.

${ }^{78}$ M. KwieK, D. ANTONOWicz, J. Brdulak, M. Hulicka, T. JĘDRZEJewski, R. Kowalski, E. KulCZYCKI, K. SZADKOWSKI, A. SzOT, J. WolszCZAK-Derlacz, Projekt zatożeń do ustawy Prawo o szkolnictwie wyższym (Poznań: Uniwersytet im. Adama Mickiewicza, 2016), 18-19. 
The need to reach a consensus in the academic community as well as to increase spendings for the entire higher education in Poland was emphasized also unanimously. When analysing these studies, it is difficult to resist the impression that all the teams are influenced by the classical figure of the university expressed both in the idea of $\mathrm{W}$. von Humboldt and in the medieval universitas studiorum. At the same time, they draw a convergent conclusion that the contemporary environment of the university not only prevents the direct reception of these ideas, but also requires a thorough redefinition of the principles of its functioning. Without questioning the values and traditions of the university developed in the centuries-old history of its mission, they postulate, following the American universities, to include aspects of academic entrepreneurship. It seems, however, that the research context of the university prevails in the concepts presented. Thus, all the expert teams referred directly to the original form of the Humboldt's idea of university, which assumed the primacy of scientific research. As we know, it was only over time, with the development of capitalism, when the demand for a high level of professional education had grown, that the Humboldt concept evolved, and the priority of research was modified to include the principle of unity of research and teaching. ${ }^{79}$

\section{MISSION OF THE UNIVERSITY \\ IN VIEW OF THE MAIN OBJECTIVES OF THE ACT 2.0}

The concepts of the three expert teams presented above underlie the new Act on Higher Education and Science, in most part in force as of October 1, $2018 .^{80}$ The Act 2.0 was mainly built on the assumption of introducing a new university management model, intended to increase its effectiveness. ${ }^{81}$

\footnotetext{
${ }^{79}$ CWYNAR, "Idea uniwersytetu w kulturze europejskiej," 56 and cited J. SZCZEPAŃSKI, Szkice o szkolnictwie wyższym (Warszawa: Wiedza Powszechna, 1976), 16 et seq.

${ }^{80}$ Act of 20 July 2018 Law on Higher Education and Science (Journal of Laws of 2018, item 1668 as amended) [Ustawa z dnia 20 lipca 2018 r. - Prawo o szkolnictwie wyższym i nauce (Dz. U. z 2018 r. poz. 1668 ze zm.)], hereinafter LHES, applies within the time limits and on the terms as set out in the Act of 3 July 2018 Introductory provisions for the Law on Higher Education and Science (Journal of Laws of 2018, item 1669 as amended) [Ustawa z dnia 3 lipca 2018 r. Przepisy wprowadzające ustawę - Prawo o szkolnictwie wyższym i nauce (Dz. U. z 2018 r. poz. 1669)], hereinafter "Introductory provisions."

${ }^{81}$ Such remarks were also made in the study Diagnoza szkolnictwa wyższego. Program rozwoju szkolnictwa wyższego do 2020 r. Część III, ed. J. Górniak (Warszawa: Wydawnictwo SSGW, 2015), 235, which also pointed to the need to make institutional/organisational and managerial modifications.
} 
A question should be asked: does the academic entrepreneurship stressed in the course of legislative work (effectiveness of action in the business environment) violate the concept of the medieval universitas studiorum? In other words, have the structural elements characterizing the classical concept of universitas studiorum remained valid and alive in the Polish legal order?

The analysis of the Act 2.0 leads to the conclusion that the main ideas have already been formulated in the introduction of the Act. It states that the functioning of higher education in Poland should be based on the desire to know the truth and to pass on knowledge from one generation to another ${ }^{82}$ higher education in Poland should be based on the desire to know the truth and to pass on knowledge from one generation to another. Science plays a fundamental role in the creation of civilization and defines the principles of the functioning of higher education and the conduct of scientific activities based on the following principles:

- it is the duty of the public authority to provide optimal conditions for the freedom of research and artistic creation, freedom of teaching and the autonomy of the academic community,

- each scholar is responsible for the quality and integrity of the research carried out by him or her and for the education of the younger generation,

- universities and other research institutions carry out a mission of particular importance for the state and the nation: they make a key contribution to the innovation of the economy, contribute to the development of culture, participate in shaping the moral standards of public life.

Undoubtedly, the introduction is intentional, ideological and indicates the legislature's motives. However, the question arises as to what legal significance can be attributed to such statements? According to the rules of legislative technique ${ }^{83}$ statutory provisions do not contain statements that are not aimed at expressing legal norms ${ }^{84}$ The lawmakers should avoid the posting of

\footnotetext{
${ }^{82}$ It is stated that the term 'functioning' has been used in its broader sense (H. IZDEBSKI, "Komentarz do art. 1," in IZDEBSKI, ZIELIŃSKI, Prawo o szkolnictwie wyższym i nauce. Komentarz).

${ }^{83}$ Section 11 of the Rules of Legislative Technique

${ }^{84}$ This also corresponds to the principle of conciseness in $\S 5$ of the Rules of Legislative Technique. In its ruling of 7 June 1989, U 15/88, OTK 1989, no. 1, item 10, the Constitutional Court, referring to the views of the established scholarly opinion, took the view that the legislative act was "an act establishing rules of a general nature (i.e. addressed to a certain class of addressees distinguished by their common characteristic) and abstract (i.e. establishing certain patterns of conduct)." This means that a feature that distinguishes egal norms from other social rules is their general and at the same time abstract nature. In its decision of 6 December 1994, U 5/94, OTK 1994, no. 2 ,
} 
non-normative statements in normative acts. It is allowed to use in legal acts elements of a purely informational nature (e.g. titles, editorial units or references) which, despite the lack of normative characteristics, are necessary for keeping the order and transparency of the normative act. However, this is not the case with elements such as appeals, postulates, recommendations, admonitions or justifications. It is argued in the literature that such non-normative statements should not be included in laws but instead, where necessary, appropriate nonnormative acts should be adopted. They have a rather ceremonial style and most often specify the motives and functions of the issued act, explaining the axiology. ${ }^{85}$

In the case of the Act 2.0, however, there is no such content in the explanatory memorandum to the draft, which is utterly laconic and neither addresses the idea nor motivation of the legislature in introducing the regulation. This poses the risk that the authorities applying the law will try to grant such statements a normative meaning, especially since there is no legal glossary in the Act. ${ }^{86}$ From the point of view of legislative technique, it is not advisable to include preambles and introductions in legal acts, all the more so as regards ordinary legislation. While this legislative solution is permissible in a Constitution, it is strongly recommended to avoid such statements in ordinary laws. ${ }^{87}$

item 41, the Constitutional Court developed those findings, concluding that: "The feature of generality relates to that part of the legal norm, which is defined as a hypothesis (the definition of the addressee and the conditions for the application of the norm) and obliges the legal authority to build the norm in such a manner in which the addressee and the circumstances of application of the norm will be determined generally and not individually. The addressee must be identified as part of a class of entities distinguished by a particular feature or features"; "abstraction concerns the subject-matter of the norm determining the required conduct of the addressee. The subject matter of the legal norm must be the class of behaviour and not the specific conduct of the addressee. The consequence of the abstraction of the norm is its repeatability - that it is not terminated or 'consumed' by a single application" (see also the decisions of the Constitutional Tribunal: of 14 December 1999, U 7/99, OTK 1999, no. 7, item 170, and of 26 October 2004, U 5/02, OTK-A 2004, no. 9, item 102). In its ruling of 21 November 1994, K 6/94, OTK 1994, no. 2, item 39, the Constitutional Court emphasised that the fact that any law must be formulated as a legislative act, i.e. it can contain only legal norms, means that the introduction into the statute the content of a specific and individual nature is inadmissible and incompatible with the Polish Constitution.

${ }^{85}$ A. SZMYT, "Opinia prawna w sprawie projektu uchwały o powołaniu komisji śledczej do zbadania zarzutu nielegalnego wywierania wpływu na funkcjonariuszy państwowych," Przegląd Sejmowy no. 3 (2008): 179.

${ }^{86}$ G. WIERCZYŃSKI, "Komentarz do rozporządzenia w sprawie Zasad techniki prawodawczej," in IDEM, Redagowanie i ogłaszanie aktów normatywnych. Komentarz (Warszawa: Wolters Kluwer, 2016), 115, LEX.

${ }^{87}$ M.M. DĘBSKA, Zasady techniki prawodawczej. Komentarz (Warszawa: Wolters Kluwer, 2013), LEX. A. CHODUŃ, M. ZIELIŃSKI, “Interpretacyjna rola wstępów aktów prawnych,” in Wokót 
The literature points out that the prohibition of such non-normative content is often disregarded in Polish legislative practice. ${ }^{88}$ It is difficult to resist the impression that this is also the case with the Introduction to the Act 2.0. Of course, this is not about abandoning the definition of the idea and motivation of the legislature, especially since this is an act that provides for an extremely complex and important reform in Polish circumstances. However, it seems that a much better solution from the point of view of the rules of correct legislation would be to include this matter in the explanatory note to the Act 2.0.

Notwithstanding the content of the introduction to the Act, its normative part ${ }^{89}$ states that "the mission of the system of higher education and science is to provide the highest quality education and scientific activities, to shape civic attitudes, as well as to participate in social development and contribute to the innovation-based economy." 90

It is worth mentioning here that the previous Law on Higher Education of 2005 states that universities, in their "mission of discovering and passing on the truth by conducting research and student education, are an integral part of the national education and science system, cooperate with the socio-economic environment, in particular in the field of research and development for economic operators." ${ }^{11}$ There is no doubt that the current regulation is much broader from the subjective point of view. It applies not only to higher education institutions, but to the system of higher education and science as

konstytucji i zdrowego rozsądku. Prace dedykowane Profesorowi Tadeuszowi Smolińskiemu, eds. J. Ciapała, A. Rost (Szczecin-Jarocin: Uniwersytet Szczeciński, et al., 2011), 25. Other laws that contain preambles are e.g. the Act of 7 October 1999 on Polish language, consolidated text Journal of Laws of no. 43 (2011), item 224 as amended; Act of 26 October 1982 on education in sobriety and alcoholism prevention, consolidated text Journal of Laws of 2012, item 1356 as amended; Act of 9 June 2011 on supporting the family and the system of foster care, consolidated text Journal of Laws of 2013, item 135 as amended; Act of 7 September 1991 on the system of education, consolidated text Journal of Laws of no. 256 (2004), item 2572 as amended.

${ }^{88}$ WIERCZYŃSKI, "Komentarz do rozporządzenia."

${ }^{89}$ Article 2 of the Act 2.0 .

${ }^{90}$ Article 2 of the Act 2.0. regulates the matter of university's mission differently than. Article 4 (3) to (4) of the Law on higher education of 2005. Article 4 of the Act of 2005 defined the 'mission of universities' only in general terms, stating that, in fulfilling their mission of discovering and passing on the truth by conducting research and educating students, universities are an integral part of the national education and scientific system. Universities cooperate with the social and economic environment, in particular in conducting research and development work for the benefit of business entities, in separate forms of activity, including through the establishment of a special purpose vehicle, as well as through the participation of representatives of employers in the development of educational programmes and in the teaching process.

${ }^{91}$ Article 4 (3) to (4) of the Act. 
a whole. Regretfully, the legislature, in using such a solution in the Act 2.0, forgot to define the concept of this system. This constitutes a serious impediment to the precise decoding of the legislature's intentions.

Moreover, even a general analysis of the wording of the provision of Article 2 of the Act 2.0 raises numerous difficulties with regard to its interpretation. Attention is drawn to the fact that the vague terms was used: "conducting the highest quality (education and scientific activities)." In the context of the assumed results of the reform, the high, prestigious expectations of its effects, such a wording was not only a vague term in the legal sense, but simply empty from a semantic point of view.

Of course, the scholarly opinion rightly points out that it is about a quality which is "the highest achievable under specific conditions," comparable to that achieved in the world's top universities. ${ }^{92}$ However, from the point of view of the rules of correct legislation, such wording is considered worthy of approval.

The statutory understanding of the mission of the higher education system refers to elements such as the formation of civic attitudes (within the higher education system), as well as the participation of higher education in social development and creation of the innovation-based economy. Those concepts are also not statutorily defined. Thus, there is nothing left but to give them a commonly used meaning. Social development means all the changes that society is undergoing, ${ }^{93}$ while "innovation-based economy" refers to the concept of innovation as the basis of the economy and may show an intention to stress the growing role of pro-innovation activities as part of the system's mission. ${ }^{94}$ One should share the view that the introduction of this concept is likely to be justified by the framework documents of the European Union, which refer to such an approach to the development of higher education. ${ }^{95}$

Notwithstanding the foregoing, it should be noted that in the drafting of the normative part of the Act, there is an inconsistency with regard to the formulated

92 J. WoźNICKI, "Komentarz do art. 2," in Prawo o szkolnictwie wyższym i nauce. Komentarz, ed. J. Woźnicki (Warszawa: Wolters Kluwer, 2019), LEX.

${ }^{93}$ See also the definition of development in the Dictionary of Polish Language (Stownik jezzyka polskiego), accessed Juni 29, 2020, https://sjp.pwn.pl/szukaj/rozw\%C3\%B3j\%20.html.

${ }^{94}$ As in WoźNICKI, "Komentarz do art. 2".

${ }^{95}$ See e.g. European Council 23-24 March 2000, The Lisbon strategy; Communication from The Commission Europe 2020, A strategy for smart, sustainable and inclusive growth, Brussels, 3.03.2010, $\operatorname{COM}(2010)$ 2020; Commission Communication of 12 November 1997: Towards a Europe of knowledge, as cited in Woźnicki, "Komentarz do art. 2." 
introduction to the Act. ${ }^{96}$ When reading the introduction, which, after all, defines the programme objectives of the reform, there is an impression that the legislature puts emphasis on the conduct of research at the university (nota bene ignoring the educational process). Meanwhile, in defining the university's mission in Article 2, it already recognises the need for research and education, but mentions education in the first place. Given that the wording is already a legal provision, it should be assumed that the so-called rational legislature deliberately defined the level of education by placing it before scientific research. On the one hand, this would be in correlation with the idea of medieval university and the Humboldt's university, but on the other hand it seems to be in clear contradiction not only with the reform objectives presented by the government, but even with the arrangement and solutions of the Act 2.0 itself. It is clear from these that the main stress is placed on scientific research, and the teaching process is of a secondary nature. This is evidenced, inter alia, by the clearly marked career path of an academic teacher based on scientific achievements (as well as evaluation), criteria for parametrisation of universities determining the amount of funding for the university, as well as a strong distinction within the group of all universities of so-called research universities treated as a priority under the Act.

\section{FINAL REMARKS}

The types of universities developed in the Middle Ages are still recognised today as models to follow. They are referred to not only in the course of lively academic discussion, but also during the legislative processes that formulate successive reforms of the higher education system. The classical university model developed by W. von Humboldt is treated with equal esteem. This seems natural, given that Humboldt firmly rooted his idea in the concept of medieval university (regardless of the later evolution of his thought).

The same models appear to have been followed at the stage of developing the concept of higher education reform and subsequently adopting the Act 2.0. However, the above analysis of the solutions of the Act allows for a conclusion that there has not been an automatic reception of the above-mentioned ideas. This cannot be a considered a flaw given the nature of the university,

${ }^{96}$ ZIELIŃSKI, "Komentarz do art. 2," in IZDEBSKI, ZIELIŃSKI, Prawo o szkolnictwie wyższym i nauce. Komentarz. Indicates that the whole Act does not emphasise an essential element, namely the fact of universities being part of the national system of science but also education. 
which is clearly influenced by the social and economic environment. These are certainly completely different from the conditions of the Middle Ages or the Humboldt's era.

However, it is necessary to assess with criticism how the provisions shaping the normative content of the university's mission have been formulated in the version of Act 2.0. The same applies to the other regulations that complement the content of the regulations defining this mission. Not only did due diligence in the context of the principles of correct legislation seem to have been lacking, but there were also no consistency in drafting a normatively coherent vision of both the mission and the model of a modern university in Poland. As it has been shown, the individual content in some paragraphs seems to be contradictory.

Nevertheless, it is worth noting the significant development of the content of the mission of university as it is understood today. Both in universitas studiorum and in Humboldt's concept, these were primarily research and education (supplemented by the educational aspect). At present, two further missions are clearly distinguished: developing contacts and influencing the environment as part of public service in the broad sense and directly influencing the development of an economy based on innovation and new technologies. There is also an additional, new and strongly promoted aspect: academic entrepreneurship. This clearly distinguishes the modern university from the medieval model and the Humboldt's one, showing the direction of evolution of the living organism of the university. Specific effects of this process will be able to be thoroughly assessed in the future, as has also been done in relation to models of ideas of medieval and modern universities.

\section{BIBLIOGRAPHY}

Act of 20 July 2018 Law on Higher Education and Science (Journal of Laws of 2018, item 1668 as amended) [Ustawa z dnia 20 lipca 2018 r. - Prawo o szkolnictwie wyższym i nauce (Dz. U. z 2018 r. poz. $1668 \mathrm{ze} \mathrm{zm}$.)].

Act of 3 July 2018 Introductory provisions for the Law on Higher Education and Science (Journal of Laws of 2018, item 1669 as amended) [Ustawa z dnia 3 lipca 2018 r. - Przepisy wprowadzające ustawę - Prawo o szkolnictwie wyższym i nauce (Dz. U. z 2018 r. poz. 1669)].

AlATAS, Syed Farid. "From Jāmi'ah to University: Multiculturalism and Christian-Muslim Dialogue." Current Sociology 54, no. 1 (2006): 112-132.

Altbach, Philip G. "The Past, Present, and Future of the Research University." In The Road to Academic Excellence, eds. P.G. Altbach, J. Salmi, 11-32. Waszyngton: The World Bank, 2011. 
Altbach, Philip G. "The Realities of Mass Higher Education in a Globalized World.” In Higher Education in a Global Society, eds. D.B. Johnstone, M.B. d'Ambrosio, P.J. Yakoboski, 25-41. Cheltenham: Edward Elgar, 2010.

ANDRZEJUK, Artur. "Universitas? Mistrz? Uczeń? O roli uniwersytetów dzisiaj." In Debaty UKSWordzkie cz. 1, eds. K. Flader-Rzeszowska, K. Marcyński, J.A. Sobkowiak, 107-108. Warszawa: Wydawnictwo Uniwersytetu Kardynała Stefana Wyszyńskiego, 2016.

BARNETT, Ronald. Realising the University in an Age of Supercomplexity. Buckingham: Society for Research into Higher Education \& Open University Press, 1999.

BASZKIEwICZ, Jan. Młodość uniwersytetów. Warszawa: Wydawnictwo “Żak”, 1997.

BednarczyK-PŁachtA, Agnieszka. Status szkoly wyższej jako podmiotu administracji publicznej. Warszawa: Wolters Kluwer, 2016.

BIEDRZYCKA, Halina. "Zagadnienie zależności “The Idea of a University” J.H. Newmana od starożytności klasycznej." Roczniki Humanistyczne 4, no. 2 (1953): 113-122.

Bollinger, Lee C. "The Idea of a University.” Wall Street Journal, October 15, 2003. www.proquest.com.

BrZEZIŃSKI, Jerzy. "Erozja norm akademickich. Próba diagnozy.” Teksty Drugie no. 1-2 (2006): 9-39.

BRZEZIŃSKI, Jerzy. “O cnotach uniwersyteckich.” In Wokót historii i polityki. Studia z dziejów XIX i XX w. dedykowane Prof. W. Wrzesińskiemu w siedemdziesiąta rocznice urodzin, eds. S. Ciesielski, T. Kulak, K. Ruchniewicz, J. Tyszkiewicz, 83-98. Toruń: Wydawnictwo Adam Marszałek, 2004.

BrZEZIŃSKI, Jerzy Marian. “Etos akademicki.” Forum Dydaktyczne no. 7-8 (2011): 9-16.

BRZEZIŃSKI, Jerzy Marian. "Doświadczenia uniwersytetu europejskiego a przyszła organizacja szkolnictwa wyższego w Polsce.” In Idea Uniwersytetu u schyłku tysiaclecia, ed. H. Żytkowicz, 89-104. Warszawa: Fundacja na Rzecz Nauki Polskiej, Wydawnictwo Naukowe Scholar, 1998.

BumP, Jerome. "Historia uniwersytetu jako instytucji naukowej." Internet Archive. Accesssed February 18, 2020. http://web.archive.org/web/20150712015657/http://www.cwrl.utexas.edu:80/ bump/ OriginUniversities.html.

CHODUŃ, Agnieszka, and Zieliński Maciej. “Interpretacyjna rola wstępów aktów prawnych.” In Wokót konstytucji i zdrowego rozsadku. Prace dedykowane Profesorowi Tadeuszowi Smolińskiemu, eds. J. Ciapała, A. Rost, 15-26. Szczecin-Jarocin: Uniwersytet Szczeciński, et al., 2011.

Constitutional Tribunal decision of 26 October 2004, U 5/02, OTK-A 2004, no. 9, item 102.

Constitutional Tribunal of 21 November 1994, K 6/94, OTK 1994, no. 2, item 39.

Constitutional Tribunal decision of 6 December 1994, U 5/94, OTK 1994, no. 2, item 41.

Constitutional Tribunal decision of 14 December 1999, U 7/99, OTK 1999, no. 7, item 170.

Constitutional Tribunal ruling of 7 June 1989, U 15/88, OTK 1989, no. 1, item 10.

Cwynar, Katarzyna M. "Idea uniwersytetu w kulturze europejskiej." Polityka i Spoleczeństwo 2 (2005): 46-59.

CzEżowski, Tadeusz. "Uniwersytet nowoczesny.” In T. Czeżowski. O uniwersytecie i studiach uniwersyteckich, 5-16. Toruń: Księgarnia Naukowa T. Szczęsny i S-ka, 1946.

CzEżowsKi, Tadeusz. "Uniwersytet nowoczesny.” In Tożsamość uniwersytetu. Antologia tekstów Profesorów Uniwersytetu Mikołaja Kopernika, ed. W. Wincławski, 13-27. Toruń: Wydawnictwo Uniwersytetu Mikołaja Kopernika, 1994.

DęBSKA, Monika Magdalena. Zasady techniki prawodawczej. Komentarz. Warszawa: Wolters Kluwer, 2013. LEX. 
DUDEK, Joanna. "Etos uniwersytetu a globalny kłopot z jego tożsamością.” Studies in Global Ethics and Global Education no. 7 (2017): 24-42.

FURMANEK, Waldemar. "Funkcje teleologiczne uniwersytetu w świetle transformacji cywilizacyjnych." In Idea uniwersytetu w nauczaniu Jana Pawła II, ed. W. Furmanek, 124-139. Rzeszów: Wydawnictwo Uniwersytetu Rzeszowskiego, 2006.

FurmaneK, Waldemar. "Wartości uniwersytetu w nauczaniu Ojca Świętego Jana Pawła II.” In Idea uniwersytetu w nauczaniu Jana Pawła II, ed. W. Furmanek, 38-62. Rzeszów: Wydawnictwo Uniwersytetu Rzeszowskiego, 2006.

GADACZ, Tadeusz. "Wstęp do wydania polskiego.” In K. Jaspers. Idea uniwersytetu, 11-27. Warszawa: Narodowe Centrum Kultury, 2017.

GADAMER, Hans-Georg. "Idea uniwersytetu - wczoraj, dziś, jutro.” In H.-G. Gadamer. Teoria, etyka, edukacja. Eseje wybrane, s. 240-257. Warszawa: Wydawnictwa Uniwersytetu Warszawskiego, 2008.

GASSET y ORTEGA, José. “Misja uniwersytetu.” Znak no. 288 (1978): 712-731.

Diagnoza szkolnictwa wyższego. Program rozwoju szkolnictwa wyższego do 2020 r. Część III, ed. J. Górniak. Warszawa: Wydawnictwo SSGW, 2015.

GRÖZINGER, Gerd, and Rodríguez-Gómez Roberto. "Managing Higher Education: Introduction." Management Revue 18, no. 2 (2007): 95-110.

HoHENDAHL, Peter Uwe. "Humboldt Revisited: Liberal Education, University Reform, and the Opposition to the Neoliberal University." New German Critique no. 113 (2011): 159-196.

HufF, Toby E. The rise of Early Modern Science. Islam, China and the West. Cambridge: Cambridge University Press, 2003.

HugH, Goddard. A History of Christian-Muslim Relations. Edinburgh: Edinburgh University Press, 2000 .

HUTNIKIEwICZ, Artur. "Żywe tradycje uniwersytetu europejskiego - odpowiedź na ankietę KUL." In Tożsamość uniwersytetu. Antologia tekstów Profesorów Uniwersytetu Mikołaja Kopernika, ed. W. Wincławski, 39-45. Toruń: Wydawnictwo Uniwersytetu Mikołaja Kopernika, 1994.

ISKRA-PACZKOwSKA, Agnieszka. "Inkluzywna a ekskluzywna rola uniwersytetu we wspólnocie.” In Idea uniwersytetu dziś. Perspektywa filozoficzna, 147-168. Rzeszów: Uniwersytet Rzeszowski, 2012.

IZDEBSKI, Hubert. "Komentarz do art. 1.” In H. Izdebski, J.M. Zieliński. Prawo o szkolnictwie wyższym i nauce. Komentarz. Warszawa: Wolters Kluwer, 2019. LEX.

IZDEBSKI, Hubert. Założenia do projektu ustawy. "Ustawa 2.0. założenia systemu szkolnictwa wyższego." Warszawa: Uniwersytet SWPS, 2017. https://wzks.uj.edu.pl/documents/41653/136919256/UAM. projekt.pdf/1e21b91d-6778-44ad-a813-dc31fce67d90.

JASPERS, Karl. Idea uniwersytetu. Warszawa: Narodowe Centrum Kultury, 2017.

KIEREŚ, Henryk. "Uczony - suweren czy funkcjonariusz?.” In Człowiek w kulturze. Jaka tożsamość uniwersytetu? no. 21 (2009/2010): 83-96.

Komorowski, Ludwik. “Idea czy utopia,” Pauza Akademicka no. 415 (2018): 2.

KRĄPIEC, Mieczysław Albert. "Otwartość uniwersytetu." In O uniwersytecie. Wykłady otwarte imienia Ojca Profesora Mieczysława A. Krapca OP, eds. A. Maryniarczyk, T. Duma, K. Stępień. Lublin: Polskie Towarzystwo Tomasza z Akwinu, 2014, 77-95. 
KRĄPIEC, Mieczysław Albert. "Uniwersytet.” In Powszechna Encyklopedia Filozofii, vol. IX, eds. M.A. Krąpiec, A. Maryniarczyk. Lublin: Polskie Towarzystwo Tomasza z Akwinu, 2000. ptta.pl/ pef/pdf/ u/uniwersytet.pdf.

KRĘGLEWSKI, Marek. "Mój uniwersytet.” In Fenomen uniwersytetu, eds. A. Grzegorczyk, J. Sójka, 3742. Poznań: Wydawnictwo Naukowe UAM, 2008.

KwIEK, Marek. Transformacje uniwersytetu. Zmiany instytucjonalne i ewolucje polityki edukacyjnej w Europie. Poznań: Wydawnictwo Naukowe UAM, 2010.

KwIEK, Marek, Antonowicz Dominik, Brdulak Jakub, Hulicka Maria, Jędrzejewski Tomasz, Kowalski Robert, Kulczycki Emanuel, Szadkowski Krystian, Szot Adam, Wolszczak-Derlacz Joanna. Projekt zatożeń do ustawy Prawo o szkolnictwie wyższym. Poznań: Uniwersytet im. Adama Mickiewicza, 2016.

LASKOWSKA, Joanna. "Pomiędzy specjalistą i humanistą - rola uniwersytetu w kształtowaniu współczesnej gospodarki." Anthropos? Czasopismo Naukowe przy Wydziale Filologicznym Uniwersytetu Śląskiego no. 18-19 (2012): 31-36.

LEKKA-KowaLiK, Agnieszka. "Dlaczego uniwersytet nie może i nie powinien być biznesem.” Przegląd Uniwersytecki KUL 27, no. 6 (2015): 10-12.

LEKKA-KowAlIK, Agnieszka. "Komodytyzacja prawdy - komodytyzacja nauki - komodytyzacja człowieka.” In Ekonomia a chrześcijaństwo. Świat biznesu przez pryzmat encyklik św. Jana Pawła II "Centesimus annus" $i$ "Laborem exercens", ed. A. Lekka-Kowalik, 193-205. Warszawa-Lublin: Instytut Papieża Jana Pawła II, Ośrodek Badań nad Myślą Jana Pawła II, 2017.

LEKKA-KowAliK, Agnieszka. “Uniwersytet jako firma usługowa - szansa czy klęska?.” Ethos no. 85-86 (2009): 52-69.

MarkOwSKI, Mieczysław. Pierwowzory uniwersytetów. Olecko: Wydawnictwo Wszechnicy Mazurskiej, 2003.

MARKOwSKI, Mieczysław. Uniwersytet Krakowski w kontekście środkowoeuropejskim późnego średniowiecza i wczesnej nowożytności. Olecko: Wydawnictwo Wszechnicy Mazurskiej, 2005.

Michaud-Quantin, Pierre. Universitas. Expressions du mouvement communautaire dans le Moyen Age Latin. Paris: Vrin, 1970

Newman, John Henry. Idea uniwersytetu. Warszawa: Państwowe Wydawnictwo Naukowe, 1990.

NOwAK, Witold M. "Idea uniwersytetu wobec nowej sytuacji kulturowej," In Idea uniwersytetu dziś. Perspektywa filozoficzna, 67-80. Rzeszów: Wydawnictwo Uniwersytetu Rzeszowskiego, 2012.

NowICKI, Andrzej. "O dostojeństwie katedr filozoficznych." Annales Universitatis Mariae Curie-Skłodowska. Sectio I 35 (2010): 153-163.

OSBORNE, John W. "John Henry Newman and the Idea of a University." The Journal of the Rutgers University Library 42, no. 1 (1980): 40-46.

Pedersen, Olaf. The First Universities. Studium Generale and the Origins of University Education in Europe. Cambridge: Cambridge University Press, 2000.

Plus ratio quam vis consuetudinis. Reforma nauki i akademii w Ustawie 2.0. Projekt założeń do ustawy Prawo o szkolnictwie wyższym, ed. A. Radwan. Kraków: Instytut Allerhanda, 2017.

SAUERLAND, Karol. "Idea uniwersytetu - aktualność tradycji Humboldta?". Nauka i Szkolnictwo Wyższe no. 2 (28) (2006): 89-96.

SAWICKI, Stefan. O uniwersytecie katolickim - zarys modelu. Lublin: Towarzystwo Naukowe KUL, 2015.

SEŃKO, Władysław. Jak rozumieć filozofię średniowieczną. Kęty: Wydawnictwo Antyk, 2001. 
SKARGA, Barbara. “O Uniwersytecie.” Białostockie Teki Historyczne 5 (2007): 9-13.

SŁAWEK, Tadeusz. Antygona w świecie korporacji. Rozważanie o uniwersytecie i czasach obecnych. Katowice: Wydawnictwo Uniwersytetu Śląskiego, 2002.

SŁAwEK, Tadeusz. "Uniwersytet, jego powaga i warunki." In Fenomen uniwersytetu, eds. A. Grzegorczyk, J. Sójka. 85-103. Poznań: Wydawnictwo Naukowe UAM, 2008.

SŁAwIŃSKA, Irena. "Idea Uniwersytetu (Review of J.H. Newman’s Idea uniwersytetu).” Ethos no. 23 (1993): 220-223.

SONDEL, Janusz. Stownik łacińsko-polski dla prawników i historyków. Kraków: Universitas, 2005.

SoSNOwSKA, Paulina. "Idea niemieckiego uniwersytetu: mit Humboldta?.” Teraźniejszość - CzłowiekEdukacja no. 4 (60) (2012): 127-142.

SosnowsKa, Paulina. "Między ciągłością i zerwaniem. Co pozostaje z Bildung?.” Kultura Wspótczesna 1 (99) (2018): 178-191.

SowA, Kazimierz Z. "Idea uniwersytetu.” In Gdy myślę uniwersytet, 11-19. Kraków: Wydawnictwo Uniwersytetu Jagiellońskiego, 2009.

STARNAWSKI, Jerzy. "O uniwersytetach średniowiecznych i ich dziedzictwie." In Uniwersytet świątynią wiedzy, 5-11. Łódź: 2007.

STEINER, George. Nauki mistrzów, trans. J. Łoziński. Poznań: Zysk i S-ka, 2007.

SuŁKOWSKI, Łukasz. Kultura akademicka. Koniec utopii?. Warszawa: Wydawnictwo Naukowe PWN, 2016.

SwIEŻAWSKI, Stefan. Dzieje europejskiej filozofii klasycznej. Warszawa-Wrocław: Wydawnictwo Naukowe PWN, 2000.

SzCZEPAŃSKI, Jan. Szkice o szkolnictwie wyższym. Warszawa: Wiedza Powszechna, 1976.

SZMYD, Jan. "Idea uniwersytetu klasycznego a jakość człowieka.” Edukacja Filozoficzna special issue (2016): 47-76.

SzMYT, Andrzej. "Opinia prawna w sprawie projektu uchwały o powołaniu komisji śledczej do zbadania zarzutu nielegalnego wywierania wpływu na funkcjonariuszy państwowych.” Przegląd Sejmowy no. 3 (2008): 179-184.

Tomala, Ludwika. "Ustawa 2.0. Pierwsza od 12 lat całościowa reforma uczelni, przygotowana w nietypowym trybie." Nauka w Polsce. Last modified September 18, 2017. http://naukawpolsce.pap.pl/ aktualnosci/news\%2C459708\%2Custawa-20/pierwsza-od-12-lat-calosciowa-reforma-uczelni.html.

TwARDOwSKI, Kazimierz. “Rozwój i organizacja uniwersytetów.” In K. Twardowski. Lwowskie wyktady akademickie, vol. I: Wyktady o idei Uniwersytetu, compiled by R. Kuliniak, D. Leszczyna, M. Pandura, Ł. Ratajczak, 231-318. Kęty: Wydawnictwo Marek Derewiecki, 2018.

"Uniwersytet mojej młodości. Z Prof. Arturem Hutnikiewiczem z UMK rozmawia Roman Erdman." Interview by Roman Erdman. In Tożsamość uniwersytetu. Antologia tekstów Profesorów Uniwersytetu Mikołaja Kopernika, ed. W. Wincławski, 59-67. Toruń: Wydawnictwo Uniwersytetu Mikołaja Kopernika, 1994.

WALtoś, Stanisław. "Korzenie współczesnego szkolnictwa wyższego - ścieżki tradycji." In Szkolnictwo wyższe w Polsce. Ustrój - prawo - organizacja, eds. S. Waltoś, A. Rozmus, 11-51. Warszawa: Wolters Kluwer, 2012.

Weber, Max. "Nauka jako zawód i powołanie.” Translated by P. Dybel. In M. Weber. Polityka jako zawód i powołanie, ed. Z. Krasnodębski, 111-140. Warszawa: Znak, 1999.

WENTA, Kazimierz. “Akademia jako źródło wiedzy oraz przestrzeń kształcenia i wychowania.” Pedagogika Szkoły Wyższej no. 1 (2011): 90-109. 
WERnER, Mateusz. "Wstęp do wydania polskiego.” In B. Readings. Uniwersytet w ruinie. Warszawa: Narodowe Centrum Kultury, 2017.

WIERCZYŃSKI, Grzegorz. "Komentarz do rozporządzenia w sprawie Zasad techniki prawodawczej." In G. Wierczyński. Redagowanie i ogłaszanie aktów normatywnych. Komentarz. Warszawa: Wolters Kluwer, 2016. LEX.

WILKIN, Jerzy. “Jaka powinna być misja uniwersytetu w warunkach przełomu cywilizacyjnego?” In Misja $i$ stużebność uniwersytetu $w$ XXI w., ed. J. Woźnicki, 25-30. Warszawa: Oficyna Wydawnicza Politechniki Warszawskiej, 2013.

Wokót historii i polityki. Studia z dziejów XIX $i$ XX w. dedykowane Prof. W. Wrzesińskiemu w siedemdziesiąta rocznicę urodzin, eds. S. Ciesielski, T. Kulak, K. Ruchniewicz, J. Tyszkiewicz. Toruń: Wydawnictwo Adam Marszałek, 2004.

WoźNICKI, Jerzy. "Komentarz do art. 2." In Prawo o szkolnictwie wyższym i nauce. Komentarz, ed. J. Woźnicki. Warszawa: Wolters Kluwer, 2019. LEX.

ZAKOwICZ, Ilona. “Idea uniwersytetu Wilhelma von Humboldta - kontynuacja czy zmierzch.” Ogrody Nauk i Sztuk no. 2 (2012): 62-74.

ZIEJKA, Franciszek. "Czy można dziś jeszcze mówić o dostojeństwie uniwersytetu?." In Idea uniwersytetu - reaktywacja, eds. P. Sztompka, K. Matuszek, 49-53. Kraków: Wydawnictwo Uniwersytetu Jagiellońskiego, 2014.

ZIELIŃSKI, Jan Michał. "Komentarz do art. 2." In H. Izdebski, J.M. Zieliński. Prawo o szkolnictwie wyższym i nauce. Komentarz. Warszawa: Wolters Kluwer, 2019. LEX.

ZIEMBIŃSKI, Zygmunt. "What Can Be Saved of the Idea of the University?." In The Idea of the University, eds. J. Brzeziński, L. Nowak, 21-26. Amsterdam-Atlanta: Rodopi, 1997.

\section{IDEA UNIVERSITAS STUDIORUM W ŚWIETLE GŁÓWNYCH ZAŁOŻEŃ USTAWY 2.0 KILKA REFLEKSJI O MISJI WSPÓŁCZESNEGO UNIWERSYTETU}

Streszczenie

Wspólnota nauczanych i nauczających stanowi podstawową przesłankę wzorca idealnej uczelni wyższej. Powszechnie przyjmuje się, że to w epoce średniowiecza stworzono uniwersytet, chociaż pierwotne oznaki akademickości pojawiały się już w starożytnej Grecji. Od początków istnienia uniwersytetów w Europie bliskie im były takie wartości, jak: prawda, autonomia, pluralizm, wolność, powszechność, które przenikały się wzajemnie w głównym nurcie procesu dążenia do prawdy. Funkcjonowanie starożytnych form działalności naukowej i kształcenia oraz powstanie pierwszych średniowiecznych uniwersytetów europejskich nieodzownie łączy się z kształtowaniem idei uniwersytetu. Proces ten nie był, i także współcześnie nie jest w swym przebiegu jednorodny. Na tym tle starano się dokonać weryfikacji i oceny głównych założeń ostatniej reformy szkolnictwa wyższego w Polsce (tzw. ustawy 2.0). Analiza obejmuje przede wszystkim przyjęte cele reformy, sposób określenia misji uniwersytetu oraz poprawność procesu legislacyjnego. Całość rozważań dokonywana jest w perspektywie średniowiecznej idei universitas studiorum. Bez wątpienia bowiem wypracowane w epoce średniowiecza typy uniwersytetów są do dziś uznawane za modele wzorcowe.

Słowa kluczowe: universitas studiorum; idea uniwersytetu; reforma szkolnictwa wyższego; uniwersytet; ustawa 2.0. 


\title{
THE IDEA OF UNIVERSITAS STUDIORUM IN VIEW OF THE PRINCIPLE GUIDELINES OF THE ACT 2.0. SOME REFLECTIONS ON THE MISSION OF THE CONTEMPORARY UNIVERSITY
}

\author{
S u m m a ry
}

The community of students and teachers is the fundamental basis of the model of ideal university. It is generally assumed that it was in the Middle Ages that the university was created, although schools of a sort of academic nature were present as early as in Ancient Greece. Since the beginnings of universities in Europe, values such as truth, autonomy, pluralism, freedom and universality have been close to them and have intertwined in the mainstream process of seeking truth. The denial of these values was detrimental to the very heart of the idea of university. The functioning of ancient forms of scientific activity and education and the emergence of the first medieval European universities are inevitably linked to the shaping of the idea of university. This is the background for the attempt to verify and evaluate the main assumptions of the last reform of higher education in Poland (the socalled Act 2.0). The analysis covers first of all the adopted objectives of the reform, the way of defining the mission of the university and the correctness of the legislative process. The whole discussion is carried out in the perspective of the medieval idea of universitas studiorum.

Keywords: universitas studiorum; idea of university; higher education reform; university; Act 2.0. 